\title{
Development of 5S rDNA-Based Molecular Markers for the Identification of Populus deltoides Bartr. ex Marshall, Populus nigra L., and Their Hybrids
}

\author{
Oleg S. Alexandrov ${ }^{1,2, *}$ and Gennady I. Karlov ${ }^{1}$ \\ 1 Laboratory of Plant Cell Engineering, All-Russia Research Institute of Agricultural Biotechnology, \\ Timiryazevskaya 42, 127550 Moscow, Russia; karlovg@gmail.com \\ 2 Centre for Molecular Biotechnology, RSAU-MTAA named by K.A. Timiryazev, Timiryazevskaya 49, \\ 127550 Moscow, Russia \\ * Correspondence: alexandrov@iab.ac.ru; Tel.: +7-499-976-6544
}

Received: 23 August 2018; Accepted: 27 September 2018; Published: 29 September 2018

\begin{abstract}
Populus L. is a tree genus that includes species with a high ability for interspecies hybridization. This process takes place in nature, and is used in poplar breeding. As a result, species identification in poplar populations and plantations is very difficult. In this study, a molecular marker system was developed for the identification of the most significant poplar species (P. nigra L. and P. deltoids Bartr. ex Marshall). The basis of the system is a polymorphism in non-transcribed spacers (NTSs) of $5 \mathrm{~S}$ rDNA. The species-specific molecular markers were tested on a number of species and hybrids of poplars. It was shown that the marker system is a powerful tool for species identification, hybrid analysis, parent identification, and poplar breeding.
\end{abstract}

Keywords: poplars; molecular markers; non-transcribed spacers (NTSs); 5S rDNA; interspecies hybridization; species identification

\section{Introduction}

Poplars (Populus L. species) are widely-used forest trees that have strategic interest for many countries in the Northern Hemisphere. Their significant role in national economics was the reason for their study by chemists, agronomists, geneticists, breeders, and others [1-3]. From a botanical point of view, species of the Populus genus are often grouped into several sections: Turanga Bge., Leucoides Spach., Aigeiros Daby, Tacamahaca Spach., and Populus (syn. Leuce Daby) [4]. Hybridization successfully occurs among species in the same section and between some sections [5-7]. This feature of poplars has long been used in breeding programs. Interspecific hybrids of poplars are widespread in urban and industrial plantations. Species identification, the distinction of species and hybrids, and the determination of parents in hybrid poplars is almost impossible by morphological analysis alone. Therefore, it is very important to apply molecular methods.

Species identification with the help of molecular markers is a promising and rapidly developing area in molecular biology. The most popular method in this area is DNA barcoding based on fragments of chloroplast DNA and ITS1-5,8S-ITS2 in 45S rDNA [8,9]. However, there are cases where analysis by DNA barcoding is difficult. First of all, difficulties arise when studying young species, species with a low rate of evolution, species with a pseudogene of DNA barcode sequences and species involved in interspecific hybridization [10]. Attempts to use DNA barcoding for Populus species identification have been made worldwide, but a single polymorphic locus (single nucleotide polymorphism, SNP) for all poplars has not been determined. Therefore, systems of different markers for poplar barcoding (and PCR-RFLP (polymerase chain reaction-restriction fragment length polymorphism) markers based on these SNPs) are repeatedly offered by many researchers [11-14]. 
In this study, we present another approach to identifying poplars. The approach involves the use of polymorphic fragments longer than SNPs to develop sequence-characterized amplified region (SCAR) markers. One of such loci is a non-transcribed spacer (NTS) of 5S rDNA. In seed plants and animals, the 5S rRNA genes (120 bp) form large arrays, in which they are separated by NTSs $[15,16]$. The length and nucleotide composition of NTSs are often detected as species-specific [17-19]. In contrast, the $120 \mathrm{bp}$ coding sequences are conserved. The NTS amplification in different species is available with the help of the same primers which have been picked up on 5S rRNA gene borders [20].

In poplars, NTSs 5S rDNA has been studied for a long time. Two NTSs with different lengths were detected by authors in Reference [21]. The presence of two NTSs is typical for black poplars, and indirectly testifies to the hybridogenic origin of these species. The NTSs of Aigeiros Daby, Tacamahaca Spach., and Populus sections have been previously sequenced and aligned [21,22]. Long polymorphic sites were found in these NTSs that can be used for the design of species-specific primers. In this article, NTS polymorphism-based SCAR markers for the identification of two important Populus species were developed and tested in experiments with a wide range of poplars and hybrids.

\section{Materials and Methods}

\subsection{Plant Material and DNA Isolation}

Poplar cuttings and young leaves were collected from 22 trees (Table 1). DNA extraction was conducted according to the protocol of Doyle and Doyle (1990) [23], with some modifications [24]. The concentration of DNA in samples was equalized. DNA quality was tested by preliminary PCR with a universal primer pair based on 5S rRNA gene (5S1: 5'-GGATGGGTGACCTCCCGGGAAGTCC-3'; 5S2: 5'-GGATGGGTGACCTCCCGGGAAGTCC-3') [20].

Table 1. Poplar tree samples and their characteristics.

\begin{tabular}{|c|c|c|c|}
\hline Species & Parents of Hybrid & Sample Name & Co-Ordinates \\
\hline \multirow[t]{5}{*}{ P. nigra $\mathrm{L}$. } & & tree\#3 & $\begin{array}{l}55^{\circ} 83^{\prime} 51.59^{\prime \prime} \\
37^{\circ} 55^{\prime} 45.48^{\prime \prime}\end{array}$ \\
\hline & & tree\#10a & $\begin{array}{l}55^{\circ} 81^{\prime} 94.18^{\prime \prime} \\
37^{\circ} 56^{\prime} 81.44^{\prime \prime}\end{array}$ \\
\hline & & tree\#15 & $\begin{array}{l}55^{\circ} 76^{\prime} 77.41^{\prime \prime} \\
37^{\circ} 56^{\prime} 47.46^{\prime \prime}\end{array}$ \\
\hline & & tree\#16 & $\begin{array}{l}55^{\circ} 76^{\prime} 78.05^{\prime \prime} \\
37^{\circ} 56^{\prime} 47.74^{\prime \prime}\end{array}$ \\
\hline & & tree\#10b & $\begin{array}{l}50^{\circ} 83^{\prime} 42.96^{\prime \prime} \\
39^{\circ} 39^{\prime} 21.76^{\prime \prime}\end{array}$ \\
\hline \multirow[t]{3}{*}{ P. deltoides Bartr. ex Marshall } & & tree\#4 & $\begin{array}{l}55^{\circ} 83^{\prime} 51.72^{\prime \prime} \\
37^{\circ} 55^{\prime} 55.98^{\prime \prime}\end{array}$ \\
\hline & & tree\#1 & $\begin{array}{l}55^{\circ} 81^{\prime} 89.74^{\prime \prime} \\
37^{\circ} 56^{\prime} 83.83^{\prime \prime}\end{array}$ \\
\hline & & tree\#13 & $\begin{array}{c}55^{\circ} 83^{\prime} 3.25^{\prime \prime} \\
37^{\circ} 57^{\prime} 52.70^{\prime \prime}\end{array}$ \\
\hline \multirow[t]{3}{*}{ P. $\times$ canadensis Moench } & P. nigra L. $\times$ P. deltoides Bartr. ex Marshall & tree\#11 & $\begin{array}{l}55^{\circ} 82^{\prime} 83.67^{\prime \prime} \\
37^{\circ} 57^{\prime} 47.36^{\prime \prime}\end{array}$ \\
\hline & & $\begin{array}{l}\text { tree\#14 } \\
\text { tree\#2 }\end{array}$ & $\begin{array}{c}55^{\circ} 83^{\prime} 5.53^{\prime \prime} \\
37^{\circ} 57^{\prime} 47.93^{\prime \prime} \\
55^{\circ} 81^{\prime} 63.37^{\prime \prime} \\
37^{\circ} 56^{\prime} 94.05^{\prime \prime}\end{array}$ \\
\hline & & tree\#17 & $\begin{array}{c}55^{\circ} 77^{\prime} 0.49^{\prime \prime} \\
37^{\circ} 56^{\prime} 56.19^{\prime \prime}\end{array}$ \\
\hline P. trichocarpa Torr. et A. Gray & & tree\#20 & $\begin{array}{l}55^{\circ} 83^{\prime} 48.51^{\prime \prime} \\
37^{\circ} 55^{\prime} 55.97^{\prime \prime}\end{array}$ \\
\hline P. maximowiczii Henry & & tree\#21 & $\begin{array}{l}55^{\circ} 83^{\prime} 52.52^{\prime \prime} \\
37^{\circ} 55^{\prime} 53.57^{\prime \prime}\end{array}$ \\
\hline P. simonii Can. & & tree\#22 & $\begin{array}{l}55^{\circ} 83^{\prime} 52.74^{\prime \prime} \\
37^{\circ} 55^{\prime} 54.93^{\prime \prime}\end{array}$ \\
\hline
\end{tabular}


Table 1. Cont.

\begin{tabular}{|c|c|c|c|}
\hline Species & Parents of Hybrid & Sample Name & Co-Ordinates \\
\hline P. candicans Ait. & & tree\#23 & $\begin{array}{l}55^{\circ} 83^{\prime} 53.31^{\prime \prime} \\
37^{\circ} 55^{\prime} 52.29^{\prime \prime}\end{array}$ \\
\hline P. alba $\mathrm{L}$. & & tree\#24 & $\begin{array}{l}55^{\circ} 81^{\prime} 46.58^{\prime \prime} \\
37^{\circ} 55^{\prime} 98.41^{\prime \prime}\end{array}$ \\
\hline P. tremula $\mathrm{L}$. & & tree\#25 & $\begin{array}{l}55^{\circ} 83^{\prime} 50.41^{\prime \prime} \\
37^{\circ} 55^{\prime} 53.78^{\prime \prime}\end{array}$ \\
\hline P. $\times$ moskoviensis R. I. Schrod. & P. suaveolens Fish. $\times$ P. laurifolia $\mathrm{Ldb}$. & tree\#26 & $\begin{array}{l}55^{\circ} 83^{\prime} 53.36^{\prime \prime} \\
37^{\circ} 55^{\prime} 54.88^{\prime \prime}\end{array}$ \\
\hline P. $\times$ sowietica pyramidalis Jabl. & P. alba L. $\times$ P. bolleana Lauche & tree\#27 & $\begin{array}{l}55^{\circ} 83^{\prime} 67.63^{\prime \prime} \\
37^{\circ} 55^{\prime} 52.73^{\prime \prime}\end{array}$ \\
\hline \multirow[t]{2}{*}{ P. $\times$ jablokovii Jabl. } & P. tremula L. $\times$ P. bolleana Lauche & tree\#28 & $55^{\circ} 97^{\prime} 77.66^{\prime \prime}$ \\
\hline & & & $37^{\circ} 89^{\prime} 60.74^{\prime \prime}$ \\
\hline P. $\times$ berolinensis K. Koch. & P. laurifolia Ldb. $\times$ P. nigra L. & tree\#29 & $\begin{array}{l}55^{\circ} 83^{\prime} 51.80^{\prime \prime} \\
37^{\circ} 55^{\prime} 55.15^{\prime \prime}\end{array}$ \\
\hline
\end{tabular}

\subsection{Analysis of Sequences and Primer Design}

Thirteen 5S rDNA fragments including NTSs of $P$. nigra and $P$. deltoides were collected from GenBank (P. nigra: AJ843800, AJ843801, AJ843802, KU994870, KU994871; P. deltoides: AJ292052, AJ292053, AJ292054, AJ292055, AJ292056, AJ292057, AJ843767, AJ843768). Sequence alignments were conducted with the help of GenDoc software [25]. NTS sequences with a low level of identity were selected for the analysis of polymorphic regions. The analysis was performed as follows. The NTS sequence of the studied species was aligned with all sequences of another species. Alignment was divided into ten-column fragments (the first column of each fragment was the second column of the previous fragment). The level of polymorphism in each fragment was calculated as the ratio of the number of polymorphic sites (nucleotides that differ from the nucleotides of the studied sequence or gaps) to the total number of sites in the fragment among all the sequences of another species. The polymorphism level in sites with gaps in the sequence of studied species was considered equal to zero. The neighboring fragments with a high level of polymorphism were used for the primer design. The design was conducted as follows. The previously designed 5S1 primer (see Section 2.1) was used as a basis to create a forward primer. The $5 \mathrm{~S} 1$ primer is annealed in the center of the conserved $5 \mathrm{~S}$ rRNA gene sequence, and can be used for a wide range of organisms.

This primer was checked with different variants of the reverse primer that is based on the above-mentioned polymorphic fragments. In order to check the primers, the Multiple Primer Analyzer and Basic Local Alignment Search Tool (BLAST) (see links in Figure S1) were used. When self-dimers and cross-primer dimers were identified, the length of the forward primer was modified and some other variant of the reverse primer was input.

The self-dimers and cross-dimer free primers are presented in Table 2. The primers were synthesized by ZAO “Synthol” (Moscow, Russia).

Table 2. The designed primers and the parameters of its use.

\begin{tabular}{|c|c|c|c|}
\hline Primer Name & Sequence & Annealing, $\mathrm{t}^{\circ} \mathrm{C}^{1}$ & PCR Product Length, bp \\
\hline $\begin{array}{l}\text { 5S1mod1 } \\
\text { NIG6-2r }\end{array}$ & $\begin{array}{l}5^{\prime} \text {-GGATGGGTGACCTCCCG-3' } \\
5^{\prime} \text {-TTCGAAGGAGCCGCGC-3' }\end{array}$ & 62.8 & 485 \\
\hline $\begin{array}{l}\text { 5S1mod2 } \\
\text { DEL121-4r }\end{array}$ & $\begin{array}{c}\text { 5'-GGATGGGTGACCTCCGG-3' } \\
\text { 5'-GGCGACCCTGGGAAGTGT-3' }^{\prime}\end{array}$ & 66.0 & 433 \\
\hline
\end{tabular}

\subsection{PCR and Electrophoresis}

The following PCR conditions were used: $94{ }^{\circ} \mathrm{C}$ for $5 \mathrm{~min}$; 30 cycles of $94{ }^{\circ} \mathrm{C}$ for $20 \mathrm{~s}, \mathrm{~N}^{\circ} \mathrm{C}$ for $20 \mathrm{~s}$, and $72{ }^{\circ} \mathrm{C}$ for $20 \mathrm{~s} ; 72{ }^{\circ} \mathrm{C}$ for $10 \mathrm{~min}$. For " $\mathrm{N}$ " values, see Table 2. PCR results were detected by electrophoresis on $2.5 \%$ agarose gel at $10 \mathrm{~V} / \mathrm{cm}$ in $0.5 \mathrm{M}$ TBE buffer using a Sub-Cell Model 192 camera 
(Bio-Rad, Hercules, CA, USA) and photographed using the gel documentation system GelDoc XR Plus (Bio-Rad, Hercules, CA, USA).

\section{Results}

P. nigra and P. deltoides 5S rDNA sequences were found in GenBank and used for NTS isolation. The alignment of the NTSs showed that 11 sequences (AJ843800, AJ843801, AJ843802, KU994870 of P. nigra and AJ292052, AJ292053, AJ292054, AJ292055, AJ292056, AJ292057, AJ843767 of P. deltoides) had a 70\%-99\% level of homology between themselves (Figure S2, Table S1). P. nigra NTS KU994871 and P. deltoides AJ843768 NTS had a 39\%-45\% level of homology with others and $64 \%$ between themselves. These two NTSs were recognized as the most promising basis for the successful development of species-specific markers. They were selected for the detailed analysis of polymorphism.

The alignment of $P$. nigra NTS KU994871 with all NTSs of $P$. deltoides consisted of 517 columns (Table S2). The analysis of 508 ten-column fragments detected three fragments with a high $(>90 \%)$ level of polymorphism (fragments 39, 40, and 469). The 14-20 bp regions containing the fragments were tested as primers. As a result, the region containing fragments 469-475 (NIG6-2r primer, Table 2) was changed for PCR assays. The alignment of P. deltoides NTS AJ843768 with all NTSs of $P$. nigra consisted of 512 columns (Table S3). The analysis of 503 ten-column fragments detected 12 fragments with a high (>90\%) level of polymorphism (fragments 21, 22, 392-399, 414, and 415). The region containing fragments 386-395 (DEL121-4r primer, Table 1) was changed for PCR assays.

PCR tests of the designed primers were conducted with all collected DNA samples of $P$. nigra, $P$. deltoides, and $P . \times$ canadensis trees. Experiments with the 5S1mod1/NIG6-2r primer pair showed an amplification of one $485 \mathrm{bp}$ fragment in cases with $P$. nigra and $P . \times$ canadensis samples (Figure 1 ). $P . \times$ canadensis fragments were dimly visualized by electrophoresis. PCR with the 5S1mod2/DEL121-4r primer pair showed an amplification $433 \mathrm{bp}$ fragment in $P$. deltoides and $P . \times$ canadensis samples (Figure 1). Additionally, the electrophoresis showed that the signal brightness of the $P . \times$ canadensis fragments was lower.
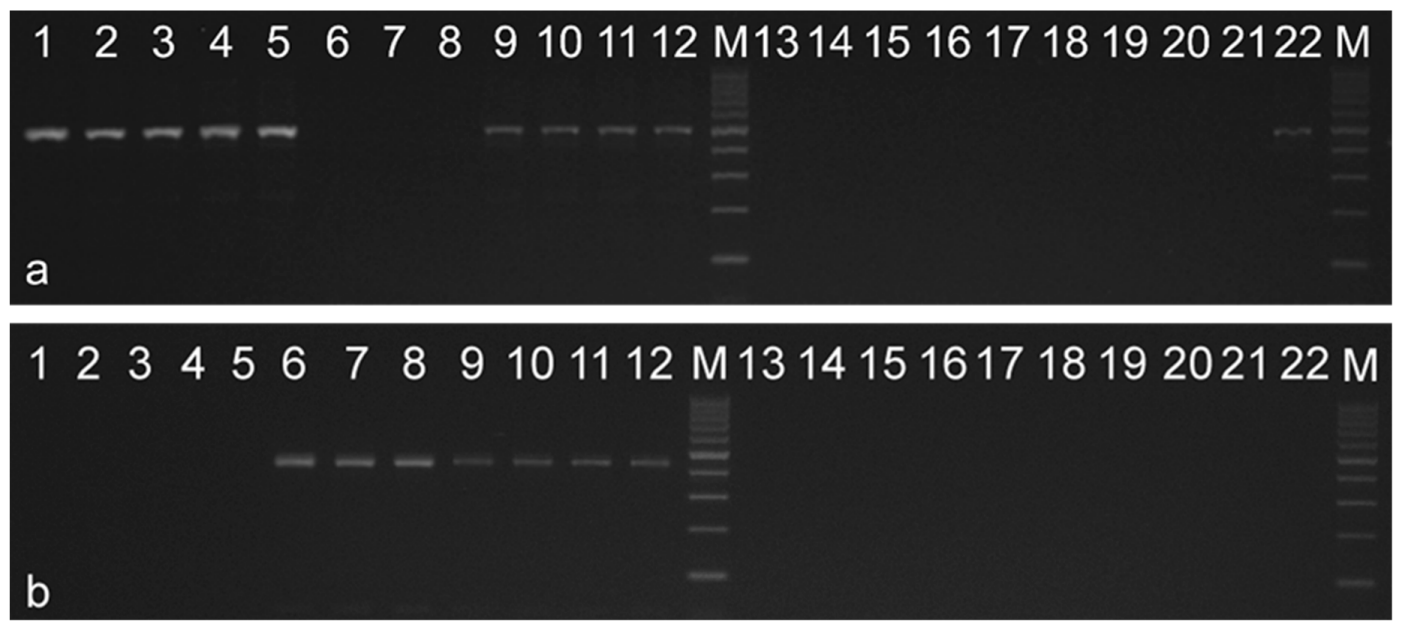

Figure 1. The electrophoresis picture with the results of the PCR (polymerase chain reaction) test: (a) with the 5S1mod1/NIG6-2r primer pair; (b) with the 5S1mod2/DEL121-4r primer pair. The numbers in both panels correspond to the following samples: $1-P$. nigra L. tree\#3; 2-P. nigra L. tree\#10a; 3-P. nigra L. tree\#15; 4-P. nigra L. tree\#16; 5-P. nigra L. tree\#10b; 6-P. deltoids Bartr. ex Marshall tree\#4; 7-P. deltoids Bartr. ex Marshall tree\#1; 8-P. deltoids Bartr. ex Marshall tree\#13; 9—P. $\times$ canadensis Moench. tree\#11; 10—P. $\times$ canadensis Moench. tree\#14; 11-P. $\times$ canadensis Moench. tree\#2; 12-P. $\times$ canadensis Moench. tree\#17; 13-P. trichocarpa Torr. et A. Gray tree\#20; 14-P. maximowiczii Henry tree\#18; 15-P. simonii Can. tree\#19; 16-P. candicans Ait. tree\#23; 17-P. alba L. tree\#24; 18-P. tremula L. tree\#25; 19-P. $\times$ moskoviensis R. I. Schrod. tree\#26; 20—P. $\times$ sowietica pyramidalis Jabl. tree\#27; 21-P. jablokovii Jabl. tree\#28; 22-P. $\times$ berolinensis K. Koch. tree\#29. 
PCR with DNA samples of other section poplars and their hybrids demonstrated no amplification in all cases. However, a weak amplification of the corresponding fragment with the 5S1mod1/NIG6-2r primer pair was observed in $P . \times$ berolinensis, which has a $P$. nigra in the parent generation (Figure 1 ).

In all described cases, the different level of the marker amplification in species and hybrids may be linked to the different number of marked $5 S$ rDNA monomers in them.

\section{Discussion}

In this study, all described NTS classes of P. nigra and P. deltoides were analyzed. It was previously reported that all P. deltoides NTSs are separated into two classes [21,22]. Additionally, Wilson (2013) asserted that $P$. nigra has one NTS class. However, Alexandrov et al. (2014) reported a second NTS class in P. nigra [26]. This study confirmed the existence of two $P$. nigra NTS classes, because the second (described by Alexandrov et al., 2014) P. nigra NTS was used as the basis for the development of an efficient $P$. nigra-specific molecular marker.

Analysis of NTS alignments revealed that the majority of polymorphic fragments corresponded to inserts in the marked NTSs of P. nigra or P. deltoides (to deletion in other NTSs of the same and second species). Consequently, the annealing of NIG6-2r and DEL121-4r primers occurred in NTSs of one corresponding class only. Such a condition complex ensured reliable work for the developed species-specific markers in this case. However, a high level of NTS polymorphism is not observed in all closely related species. In cases where the polymorphic regions are short and cannot serve as a basis for primer development, molecular markers of other types can be created. For example, short polymorphic regions can be used to develop RLFP, SNP, or CAPS (cleaved amplified polymorphic sequences) markers [14,27]. Thus, the approaches for the development of species-specific markers presented in the article are not universal. However, they can be used in cases similar to this one. For example, they will be useful for marking some other poplar species.

Despite the importance of the presented approaches, the developed markers have a scientific value in themselves. They can be used as a tool for P. nigra, P. deltoides, and P. $\times$ canadensis identification in genetic or ecological studies, in dendrological and breeding practice (especially in the aphyllous period of the year), as well as in the analysis of other poplar hybrids. It is worth noting that the application of the markers requires conditions which exclude a PCR failure (because it may be taken as a false negative result). Most importantly, the quality of the used DNA must be high. The authors recommend testing DNA in a preliminary PCR experiment with universal $5 S$ rRNA gene-based primers such as 5S1/5S2 primers [20].

Supplementary Materials: The following are available online at http:/ / www.mdpi.com/1999-4907/9/10/604/s1, Figure S1: The Multiple Primer Analyzer link, Figure S2: The alignment of all described P. nigra and P. deltoides 5S rDNA NTSs, Table S1: The levels of homology between the described P. nigra and P. deltoides 5S rDNA NTSs, Table S2: The results of the polymorphism level analysis in ten-column fragments of KU994871 P. nigra 5S rDNA NTS, Table S3: The results of the polymorphism level analysis in ten-column fragments of AJ843768 P. deltoides 5S rDNA NTS.

Author Contributions: O.S.A. and G.I.K conceived and designed the experiments, and formulated the discussion; O.S.A. performed the experiments, analyzed the data, and wrote the paper.

Acknowledgments: The authors are grateful to A.N. Sorokin (Department of tropical and subtropical plants, Main Botanical Garden named by N.V. Tsitsin, RAS), T.G. Machrova (Department of breeding, genetics and dendrology, Mytischi Branch of Bauman Moscow State Technical University), T.A. Feodorova (Department of Higher Plants, Biology Faculty, Lomonosov Moscow State University), and N.C. Potapenko (Research Institute Botanical Garden, Nizhni Novgorod State University named after N.I. Lobachevsky) for the help in plant material collection.

Conflicts of Interest: The authors declare no conflict of interest.

\section{References}

1. Kačík, F.; Ďurkovič, J.; Kačíková, D. Chemical profiles of wood components of poplar clones for their energy utilization. Energies 2012, 5, 5243-5256. [CrossRef] 
2. Pannacci, E.; Bartolini, S.; Covarelli, G. Evaluation of four poplar clones in a short rotation forestry in central Italy. Ital. J. Agron. 2009, 4, 191-198. [CrossRef]

3. Joshi, C.P.; Thammannagowda, S.; Fujino, T.; Gou, J.Q.; Avci, U.; Haigler, C.H.; McDonnell, L.M.; Mansfield, S.D.; Mengesha, B.; Carpita, N.C.; et al. Perturbation of wood cellulose synthesis causes pleiotropic effects in transgenic aspen. Mol. Plant 2011, 4, 331-345. [CrossRef] [PubMed]

4. Eckenwalder, J.E. Systematics and evolution of Populus. In Biology of Populus and Its Implications for Management and Conservation; Stettler, R.F., Bradshaw, H.D., Jr., Heilman, P.E., Hinckley, T.M., Eds.; NRC Research Press: Ottawa, ON, Canada, 1996; Part I; pp. 7-32.

5. Willing, R.R.; Pryor, L.D. Interspecific hybridization in poplar. Theor. Appl. Genet. 1976, 47, $141-151$. [CrossRef] [PubMed]

6. Vanden Broeck, A.; Cox, K.; Quataert, P.; Van Bockstaele, E.; Van Slycken, J. Flowering phenology of Populus nigra L.; P. nigra cv. italica and $P . \times$ canadensis Moench. And the potential for natural hybridisation in Belgium. Silvae Genet. 2003, 52, 280-283.

7. Meirmans, P.G.; Lamothe, M.; Gros-Louis, M.-C.; Khasa, D.; Périnet, P.; Bousquet, J.; Isabel, N. Complex patterns of hybridization between exotic and native North American poplar species. Am. J. Bot. 2010, 97, 1688-1697. [CrossRef] [PubMed]

8. Alvarez, I.; Wendel, J.F. Ribosomal ITS sequences and plant phylogenetic inference. Mol. Phylogenet. Evol. 2003, 29, 417-434. [CrossRef]

9. Mort, M.E.; Archibald, J.K.; Randle, C.P.; Levsen, N.D.; O'Leary, T.R.; Topalov, K.; Wiegand, C.M.; Crawford, D.J. Inferring phylogeny at low taxonomic levels: Utility of rapidly evolving cpDNA and nuclear ITS loci. Am. J. Bot. 2007, 94, 173-183. [CrossRef] [PubMed]

10. Shneyer, V.S. DNA barcoding of animal and plant species as an approach for their molecular identification and describing of diversity. Zhurnal Obshchei Biol. 2009, 70, 296-315.

11. Meirmans, P.G.; Lamothe, M.; Périnet, P.; Isabel, N. Species-specific single nucleotide polymorphism markers for detecting hybridization and introgression in poplar. Can. J. Bot. 2007, 85, 1082-1091. [CrossRef]

12. Feng, J.; Jiang, D.; Shang, H.; Dong, M.; Wang, G.; He, X.; Zhao, C.; Mao, K. Barcoding poplars (Populus L.) from western China. PLoS ONE 2013, 8, e71710. [CrossRef] [PubMed]

13. Kersten, B.; Voss, M.-M.; Fladung, M. Development of mitochondrial SNP markers to differentiate Populus species. Trees 2015, 29, 575-582. [CrossRef]

14. Schroeder, H.; Kersten, B.; Fladung, M. Development of multiplexed marker sets to identify the most relevant poplar species for breeding. Forests 2017, 8, 492. [CrossRef]

15. Apples, R.; Gerlach, W.L.; Dennis, E.S.; Swift, H.; Peacock, W.J. Molecular and chromosomal organization of DNA sequence coding for the ribosomal RNAs in cereals. Chromosoma 1980, 78, 293-311. [CrossRef]

16. Perina, A.; Seoane, D.; González-Tizón, A.M.; Rodŕıguez-Fariña, F.; Martínez-Lage, A. Molecular organization and phylogenetic analysis of 5S rDNA in crustaceans of the genus Pollicipes reveal birth- and death evolution and strong purifying selection. BMC Evol. Biol. 2011, 11, 304. [CrossRef] [PubMed]

17. Pendás, A.M.; Morán, P.; Martínez, J.L.; Garcia-Vásquez, E. Applications of 5S rDNA in Atlantic salmon, brown trout, and in Atlantic salmon x brown trout hybrid identification. Mol. Ecol. 1995, 4, 275-276. [CrossRef] [PubMed]

18. Asensio, L.; Gonzalez, I.; Fernandez, A.; Cespedes, A.; Rodriguez, M.A.; Hernandez, P.E.; Garcia, T.; Martin, R. Identification of Nile perch (Lates niloticus), grouper (Epinephelus guaza), and wreck fish (Polyprion americanus) fillets by PCR amplification of the 5S rDNA gene. J. AOAC Int. 2001, 84, 777-781. [PubMed]

19. Campo, D.; Machado-Schiaffino, G.; Horreo, J.L.; Garcia-Vazquez, E. Molecular organization and evolution of 5S rDNA in the genus Merluccius and their phylogenetic implications. J. Mol. Evol. 2009, 68, 208-216. [CrossRef] [PubMed]

20. Falistocco, E.; Passeri, V.; Marconi, G. Investigations of 5S rDNA of Vitis vinifera L.: Sequence analysis and physical mapping. Genome 2007, 50, 927-938. [CrossRef] [PubMed]

21. Negi, M.S.; Rajagopal, J.; Chauhan, N.; Cronn, R.; Lakshmikumaran, M. Length and sequence heterogeneity in $5 \mathrm{~S}$ rDNA of Populus deltoides. Genome 2002, 45, 1181-1188. [CrossRef] [PubMed]

22. Wilson, N. Genome Analysis of Populus Species: Assessment of Genetic Diversity of P. deltoides, Characterization of Wide Hybrids and Phylogenetic Analysis Using Molecular Markers. Ph.D. Thesis, Teri University, New Delhi, India, 2013.

23. Doyle, J.J.; Doyle, J.L. Isolation of plant DNA from fresh tissue. Focus 1990, 12, 13-15. 
24. Razumova, O.V.; Alexandrov, O.S.; Divashuk, M.G.; Sukhorada, T.I.; Karlov, G.I. Molecular cytogenetic analysis of monoecious hemp (Cannabis sativa L.) cultivars reveals its karyotype variations and sex chromosomes constitution. Protoplasma 2016, 253, 895-901. [CrossRef] [PubMed]

25. GeneDoc: Analysis and Visualization of Genetic Variation. Available online: http:/ /www.nrbsc.org/gfx/ genedoc/ebinet.htm (accessed on 20 August 2018).

26. Alexandrov, O.S.; Karlov, G.I.; Sorokin, A.N.; Potapenko, N.C. Development of the molecular marker system for species identification of poplars and analysis of hybrids. In Proceedings of the III (V) All-Russia Youth Conference with Participation of Foreign Scientists "Prospects of Development and Problems of Modern Botany", Novosibirsk, Russia, 10-14 November 2014; Asbaganov, S.V., Ed.; Akademizdat: Novosibirsk, Russia, 2014; pp. 123-124.

27. Alexandrov, O.S.; Divashuk, M.G.; Karlov, G.I. Development of the ST/J/V-genome specific molecular marker on basis of 5S-rDNA polymorphism. Mosc. Univ. Biol. Sci. Bull. 2018, 73, 18-23. [CrossRef]

(C) 2018 by the authors. Licensee MDPI, Basel, Switzerland. This article is an open access article distributed under the terms and conditions of the Creative Commons Attribution (CC BY) license (http://creativecommons.org/licenses/by/4.0/). 